\title{
Effects of The Implementation of Strategic Management Practices on The Performance of Ktda Factories in Kisii County; Kenya.
}

\author{
Bernard Ogwoka Nyakwana ${ }^{1}$, Dr. Wallace Atambo ${ }^{2}$ \\ ${ }^{1,2}$ Jomo Kenyatta University Of Agriculture And Technology \\ Department Of Commerce And Economics Studies, Nairobi, Kenya
}

\begin{abstract}
The research study sought to unravel marketing strategic practice, strategic planning and outsourcing strategy employed by the KTDA managed factories against performance. The study also established why there is pronounced disparities in performance yet they are all managed by the same agency (KTDA). The study in particular investigated why there is varied bonus payments per kilo in various KTDA factories. Also the study discovered why there is a yield gap between KTDA factories and large estates sector. The study focused on all the KTDA factories in Kisii County. A survey design was used and a census study as the sampling procedure. The target population was 54 respondents comprising of 6 factory unit managers and 6 production managers, 6 field service coordinators and 36 directors (6 from each factory). A total of 48 respondents out of 54 filled in the questionnaires and returned them. This accounts for $88.9 \%$ response rate. The study used both primary and secondary data. Primary data was collected using questionnaires while secondary data was collected using published journals and past research studies. A pilot pre-test study was conducted to ensure validity and consistency of research instruments. Descriptive statistics was used to analyze data from which conclusions and recommendations were drawn. The study found that the strategic management practices in question positively or negatively affect performance. The study revealed the inadequate marketing, planning and outsourcing practices negatively affect factory performance. The study concludes that marketing and planning are important in organizational performance. These strategies if well drafted and executed can greatly improve the performance of KTDA factories. The study recommends that KTDA factories should permanently employ professionally trained marketers to market and sell the processed tea leaves.For planning, the factories should plan well in advance to ensure all the required resources like fuel is enough and ever in stock. On outsourcing, the factories should also make advance arrangements and agreements with other neighbouring KTDA factories to prioritize and process the outside tea alongside their own to reduce spoilage.
\end{abstract}

Keywords: Strategic Planning,Outsourcing, Kenya

\section{Introduction}

After World War II the concept of strategy fully entered into the business world. It has grown significantly leading to an increase in organizational complexity with an accelerated pace of environmental changes. The term has had several meanings different in scale and complexity which can mean policies, objectives, tactics and goals( Ansoff ,1965).

In organizational contexts the term strategy has been given diverse meanings by different authors. Benard (1938) defines strategy as what matters for the effectiveness of the organization. The external point of view, which stresses the relevance of the objectives against the environment in terms of internal stresses, the balanced communication between members of the organization and a willingness to contribute towards actions and achievement of common objectives.A well formulated and executed strategy has a number of merits to an organization. Such advantages include the following; one, it places an organization on a strong competitive position on the market and therefore achieves the desired outcome. It gives a company a competitive advantage which is the key for obtaining high revenue and a long term success. Less profitable organizations are those that lack good strategy. They lack effective ways to compete more successfully. They often under estimate the strategy of competitors and overestimate the ability of their organizations to offset the competitive advantage of the market leaders.Kalger\&Malik(1975).The second reason for executing a strategy is in regard to achieving the organizational goal. An organization cannot attain its desired goal if it does not have a good strategy on how to go about it. It will only be in constant attempt and struggle to attain it in vain. A strategy works as a guideline and a means of attaining the desired goal.Effective utilization of resources both human and material is as a result of use of a strategy. A well formulated strategy spells out clearly what to be done, by who or what and how to be done. Yoo\&Digman(1970).

To Kimura et.al (1999), tea is the second most popular beverage after coffee. The plant scientifically called Camellia sinensis is known for its caffeine. Tea is believed to have originated in China as medicinal drink. In the $17^{\text {th }}$ Century, it spread to the UK. According to the UN Food and Agricultural Organization report 
of 2013, the following are the leading ten countries in production of tea. The leading is China, India, Kenya, Sri Lanka, Turkey, Indonesia, Vietnam, Japan, IvoryCoast and Argentina.

In china the tea production industry has rapidly increased the share of China's beverage market over the past decade from $7.0 \%$ of the total domestic beverage volume in 2000 to 26.0 percent in 2013 . The tea production industry in China produces tea beverages of different types, including black, green, oolong and flower tea. These industries also produce other soft beverages such as energy drinks, fruit tea as carbonated tea. All these are strategies that the companies employ to make them competitive and hence remain relevant in the industry.Kimura et.al (1999).For Sri Lanka, it is renowned to produce Ceylon tea with a high quality aroma and taste. The country employs a number of strategies to make its tea industry competitive. One, it is the largest producer and exporter of orthodox tea with the ability to produce tea throughout the year. Diversity in specific aromas and flavors is another comparative advantage. There is also tea production of the cleanest tea in the world in terms of minimum pesticides and residues. All these factors have placed Sri Lanka on a favourable competing front in tea production.Tea factories in Sri Lanka are mostly found on tea estates which is a major account for freshness and to minimize the costs and time between plucking and processing. Kinyili(2003).

In Africa, the tea industry is not performing that well. For instance in 2014 over supply of the product to the world market had hurt the industry due to a glut in the global market (Khisa 2015). Industry regulatory authorities in Rwanda, Uganda, Burundi and Kenya confirmed that increased tea supplies due to favourable weather conditions resulted to a glut in the international market, and consequently leading to a fall in prices. With this stiff competition, there is need to embrace new strategic management practices to favourably compete in the industry.

Rwanda for instance targeted to increase production capacity to 31 million kilogrammes in 2015 (Khisa 2015). To meet this ambitious target, it means the country has to formulate and execute favourable strategic management practices beforehand.The country produces high quality tea a thing that has made it competitive. Because of this high quality, it fetches the highest prices at the weekly tea auctions in Mombasa. As a result, the Rwandan government is encouraging the planting of more tea estates and wants to build five more factories to process the raw leaf adding to the eleven factories currently in use. (Khisa 2015). Other strategies to be embraced by the Rwandan government to maintain the tea industry competitive is modernizing of the existing tea factories and road improvements to allow prompt delivering from fields to factories.In Kenya tea was first introduced in Limuru in 1903 from India by G.W.L Caine a European settler. The country is the leading producer of the crop in Africa and third in the world.Commercialized farming of tea in Kenya started in 1924 and smallholder subsector started in 1950s.Nyangito(2001).To Nyangito, most tea growing regions in Kenya are Great Rift Valley region; regions like Nandi, Aberdare, highlands, Kericho highlands, Bomet, Kiambu, Limuru, Kisii highlands, Nyeri,etc. There are many players in the tea sector in Kenya. Some of these include the Tea Board which is mandated to research and carry out promotion of tea. Other organs include the Kenya Tea Growers Association (KTGA),Tea Research Foundation of Kenya for carrying out research on tea.There is also the East African Tea Trade Association (EATTA). It brings together tea producers, brokers, tea packers buyers and warehouse people. There is also the Mombasa Tea Auction which is based in Mombasa. It is basically concerned with the selling of tea to the outside market.

There is finally the Kenya Tea Development Agency (KTDA).In 1963, there was the formation of Special Crop Development Authority (SDCA) that was meant to carry out research on crop husbandry and tea processing. The SCDA was then changed into the Kenya Tea Development Authority through an act of parliament. In 1990s, the government liberalized the tea sector to ensure the elimination of bureaucracy in tea production. Through this liberalization, the government decreased its control over the Kenya Tea Development Authority and the parastatal was changed to the Kenya Tea Development Agency (KTDA) which was not answerable to the government. KTDA is currently the largest tea manufacturing agency in the world managing 66 tea factories in the small sub holder sub sector in Kenya. There are though other tea factories which are not managed by KTDA. For instance James Finlay LTD and Unilever Tea Kenya LTD.Tea Board of Kenya report (2012).The first small holder KTDA tea factory in Kenya was established in Nyeri in 1957 called Ragati tea factory.KTDA management services Ltd provides management services to the tea factory companies. It manages tea cultivation, collects tea, delivers it to factories, processes green tea into tea, and provides technical and financial management to the farmers. The KTDA factories are grouped into 7 regions. Region 1 and 2 are the Aberdare Ranges, region 3 is Mt Kenya region, 4 is Mt Kenya and Nyambene 5 is Kericho Highlands, 6 is Kisii Highlands and 7 is Nandi Hills and Western Highlands. Nyangito(2001).

In region 6 (the Kisii Highlands), it has 12 KTDA factories. Of the 12, 6 are in Kisii county.These are, Nyamache, Itumbe, Eberege, Ogembo, Rianyamwamu, and Kiamokama. Each factory has 6 zones headed by directors who are elected by shareholders (the farmers). In this case there are 36 directors in Kisii county KTDA tea factories. The directors are in charge of oversight of the factories. The board of management at KTDA head office draft strategies. Within the factories, there is the factory unit manager in charge of the overall running of the factory. He also comes up with workable strategies. There is also the production manager in charge of the 
processing of quality tea. He supervises all the stages in tea processing. He is also in charge of tea tasting and remains answerable to the unit manager for production of quality tea. There is also the field services coordinator previously referred to as leaf base manager. He co-ordinates field activities like green leaf collection, ensures buying of quality tea leaves, prompt delivery of green tea to factories, organizes field days for trainings among other field related operations. There is equally the supervisor in charge of tea production process. He is in charge of the casual employees in the production process. He advises the production manager on what to be done in the processing procedures like when production workers are to be added or reduced depending on quantity of green leaves supplied. Nyangito(2001).

In the production process, tea is processed into different grades. KTDA factories produce two broad grades thus primary grade and secondary grade. Primary grade further produces two sub- grades; Broken Pekoe 1(BP1) and Broken Pekoe 2 (BP2). BP1 is the best and is purely meant for export.Tea Board of Kenya report.(2012).In dry weather much of the secondary grade is produced which is full of fiber because of the limited water content in the plucked green tea leaves. Conversely in excessive rainy seasons the production costs escalate because a lot of fuel is used in reducing the excessive water content in the tea leaves to reduce it to the required moisture percentage. With these challenges, the processing factories have to device strategic practices to mitigate these factors.

\section{Statement of the Problem}

Organizations in their endeavor to succeed economically, managers have always noticed that some companies flourish while others, despite their continuous struggle come to nothing but a loss. The reason behind these differences is simply the embracing of appropriate strategies for the successful ones or the employment of inappropriate strategies for the failing organizations. KTDA managed factories country wide register varied performance indices like volume of processed tea leaves and bonus payment per kilogramme per factory. This means there is a shortcoming in the way the respective factories are managed given that the factories in question are basically strategic business units.

According to the Kenya Tea Board report 2015, green tea production volume vis-à-vis sales volume has been fluctuating over time. This fluctuating trend is evident with the production of 328.2 Million kilogrammes in 2005, 369.3 Million kilogrammes in 2007 while in 2014, production stood at 444.8 Million Kgs. There has also been pronounced disparities and fluctuations in bonus payments per kilo in the different KTDA factories much as they are all managed by the same agency. For example in 2014, the highest bonus paid was Ksh.26.50cts which was Imenti tea factory and the lowest was Ogembo which was paid Ksh.8.50cts. Such discrepancies is a clear indicator that there are untackled issues in the way the factories are managed and could be due to inadequate application of strategic management practices which affect performance of the various factories. To Kimpili (2003), KTDA produce about 60\% of made tea in Kenya. Despite the development of appropriate production technologies, KTDA managed factories still experience sub-optimal performance as well as declining crop yield in comparison to large estates. The below average performance and declining crop yield in KTDA factories could also be attributed to inadequate application of strategic management practices by KTDA managed factories.

Owuor et.al (2001) found that recently developed clones produce to a tune of $4000 \mathrm{~kg} / \mathrm{hectare}$ of made tea by large tea growers but a mere $2075 \mathrm{~kg} / \mathrm{hectare}$ has been realized by the KTDA factories from the same clone; same acreage. This yield gap between the two sub-sectors could be due to the inadequate application of strategic management practices by KTDA managed factories. If appropriate strategic management practices could be embraced by KTDA factories, the two sub- sectors could compete favourably and bridge the pronounced gaps. This research sought to assess effects of strategic management practices on the performance of KTDA factories in Kisii County.

\section{General Objective}

The general objective of the study was to establish the effects of strategic management practices on the performance of KTDA factories in Kisii County.

\section{Specific Objectives}

i. To investigate the effects of green tea marketing strategic practice on the performance of KTDA factories in Kisii county.

ii. To establish the effects of strategic planning on the performance of KTDA factories in Kisii county.

iii. To establish the effects of outsourcing strategic practice on the performance of KTDA factories in Kisii county. 


\section{Literature Review}

The following theories and models constitute the theoretical framework on which this research study is built on.

\section{Game theory}

Game theory was propounded by Antoine Courtnot in 1838. The theory entails the study of strategic decision making whereby individuals or organization can counter one another while competing. It involves the identification of the most effective and appropriate set(s) of strategies for effective managerial decision making.In game theory, decision making processes involve several players making choices that potentially affect the interests of other players; to the advantage of the strategy executer. In management, if a player makes a decision that outwits the competitor, it will certainly place the executor at a strategic advantage.

\section{Resource Based View (RBV) theory}

Another theory that will back the study is Resource Based View (RBV) theory. Birger Wernerfelt 1984 states that RBV is a basis for the competitive advantage of a firm. These resources are tangible and intangible assets at the firm's disposal if well applied can create synergy and enable a firm formulate a strategy which can place an organization at a competitive advantage. To Birger, the resources must be valuable, rare, inimitable and non-substitutable (VRIM). Resource-Based View offers some insights as to what defines strategic resources and furthermore what enables to generate profits.

\section{Conceptual Framework}

\section{Independent Variables}

\begin{tabular}{|l|c|}
\hline Strategic Management Practices & Performance \\
- Marketing strategy & $\longrightarrow$ \\
- Strategic planning & - level of revenue generated \\
- Technological strategy & - Volume of tea produced \\
- Outsourcing strategy & - Quality of tea produced \\
- Corporate governance strategy & \\
\hline
\end{tabular}

Fig.1 Conceptual Framework

In the above conceptual framework, the strategic management practices which are; marketing strategy, strategic planning and outsourcing strategy determine level of revenue, volume and quantity of tea produced which are performance indices.

\section{Empirical Review of Literature}

Green tea marketing strategy and organizational performance

Afande(2015), studied on the influence of green marketing strategy on performance of the Kenyan Sector. The study focused on marketing strategies employed in marketing of green tea and its influence of performance in terms of net income. A descriptive survey was used on factories operating under East Africa Tea Association. A sample of 63 factories was used. The study findings reveal that adoption of green marketing strategy was positively related to the performance. It is not clear whether the strategies in the study will yield the same results in KTDA factories. The study concluded that the optimal performance, appropriate strategic marketing practices be employed if maximum returns (sales) is to be realized. From Afande's study, as much as he was dealing with performance of tea, he considered tea factories under East Africa Tea Association. Conversely, my study targeted tea factories under KTDA in a small locale (Kisii County)Afande also considered only marketing strategies in relation to performance. My study equally considered other strategic practices like embracing of new technology, strategic planning, outsourcing strategy and corporate governance strategy .These variables are not investigated in Afande's research. Omari (2015), also studied on marketing strategy, firm size, liberalization and technology on the performance of KTDA factories. He found that these variables affect performance of KTDA factories. He studied on how these variables determine the export performance of KTDA factories in Kenya. He took a sample of 21 factories. In his findings he established that marketing strategy, firm size, liberalization and technology are critical determinants of export performance of 
KTDA managed factories. He further established that export performance in the industry is affected by massive over production collapsing prices, deteriorating quality, poor marketing strategy, lack of value addition and the growing inequality along the value chain. The moderating variable was the government policy which was found to have a negative effect on the export performance of tea in Kenya.Omari in his research concluded that for the industry to register a remarkable export performance of the finished product, an appropriate strategy should be formulated and carefully executed. Also the size of the firm should be optimal to cater for economies of scale.Also the organization should embrace modern advanced technology to lower costs of production and increase quality of the finished product enabling it to compete in the global market.

There is a shortcoming to Omari's research in the sense that marketing strategy only affects the finished product; well knowing before getting the finished product, there is the processing part that deals with the green tea. The green tea as a raw material needs to be of high quality and competitively be processed. All these have an impact on the performance of the tea industry. My research considered other strategies employed in processing like outsourcing and planning and how they affect performance at large. These strategies have not been considered in Omari's study.

\section{Strategic planning and organizational efficiency in tea factories.}

Okelo et.al (2015) also studied on the effects of strategic planning on organizational efficiency in tea factories in Kisii County. They found out that for a strategy to work and influence organizational efficiency, there should be adequate planning on how best to execute the strategy. From the research, Okelo et.al concluded that a company needs stronger and more dominant leadership at all levels to plan if all these strategies are to work.From the findings this was not the same in strictly KTDA managed factories because their managerial practices are different. Also, Okelo's research study looked at efficiency only as opposed to general performance. My study sought to establish the effects of strategic management practices on the overall performance.

\section{Outsourcing strategy and organizational performance of KTDA factories.}

Further research has been conducted on strategy and performance. Lijoodi 2013 in his study on outsourcing and performance of KTDA factories in Kenya, he established that outsourcing as a management strategy improved efficiency in internal operations, customer satisfaction as well as improved performance. It also established that quality of final product improved. It was however established that morale of workers went down due to outsourcing. He concluded that there is a strong correlation between outsourcing and performance. From this study, it only considered outsourcing and how it impacts on organizational performance. My study on the contrary considered different strategies alongside outsourcing like, marketing ,technology, planning, outsourcing as well as governance and how they affect performance. Lijoodi's study is also ambitious in the sense that it focuses on all KTDA managed factories in Kenya. My study will narrow down and focus on only KTDA factories in Kisii County.

\section{Research Design}

\section{Research Methodology}

The study employed a survey design. Survey design was ideal and appropriate to this study because the population under study is spread over a wide region (Creswell 2003). Also survey design enables a researcher to collect quantitative data enabling one to use descriptive statistics. Saunders et.al (2009). Above all it is effective, cheap, and easy to conduct.

\section{Target Population}

To Mugenda and Mugenda (2003) the target population is the population to which the researcher wanted to generalize the results of the study. The study locale was the whole of Kisii County comprising of 9 Sub-counties that is Bobasi, Bonchari, Bomachoge, Borabu, Kitutu Chache/North, Kitutu Chache South, Nyaribari chache, Nyaribari Masaba, and South Mugirango. There are 6 factories which were easily accessible for they are not distantly located from one another. The target population was 54 respondents consisting of 6 factory unit managers (one from each factory), 6 production managers, (also one from each factory), 6 field services coordinators (one from each factory). There were also 36 directors 6 from each factory bringing a total of 54 respondents.

\section{Sample Design}

Purposive sampling technique was used targeting only respondents who work in the targeted KTDA factories for they have the required information. 


\section{Sample size and sampling procedure}

The study employed a census study by collecting data from all the 54 respondents of the target population comprising of all unit managers, production managers, field services coordinators and factory directors.

\section{Research instruments and data collection}

Data used in this research was gotten from primary sources obtained from the research instruments as well as secondary sources like published journals and past research studies. The research used questionnaires administered to all respondents. The questionnaires constituted multiple choice questions as well as open and closed ended questions. Multiple choice questions elicited immediate responses while, open ended questions give the respondents room to express their opinions. The questionnaires were easy to administer to many respondents within a short time. Also because the questions were the same to all respondents, distortions were greatly minimized.

\section{Data Analysis and Presentation}

Data collected was analyzed using descriptive statistics which involved use of percentages, frequency tables, graphs and charts. Also a seven point Likert scale was used to establish the strength of the relationship of the variables.

\section{Results And Discussion}

Descriptive statistics was used to discuss the findings of the study. The study targeted 54 respondents from which 48 respondents filled and retuned the questionnaires making a response rate of $88.9 \%$. This response rate is more than adequate and commendable for the research. To Mugenda and Mugenda (2003), anything that surpasses 50\% response rate is adequate for analysis in descriptive study. To Creswell (2003), a 40\% response rate is ideal. For my case the response rate of $88.9 \%$ is quite sufficient. Only $11.1 \%$ failed to return the questionnaires. The implication to such a response rate suggest adequate co-operation of the respondents to participate in the research.

\section{Green tea marketing strategy on performance}

The study investigated on the effects on the green tea marketing strategy and how it affects performance in terms of level of revenue generated.

Table 1: Direct tea marketing by Factories.

\begin{tabular}{|c|c|c|}
\hline Response & Frequency & Percentage \\
\hline Yes & 4 & 8 \\
No & 44 & 92 \\
\hline Total & 48 & 100 \\
\hline
\end{tabular}

From table 1 above, 4 respondents asserted that the factories have a direct involvement in the marketing of the processed tea leaves. 44 respondents on the other hand claimed that the factories do not directly involve themselves in marketing the processed green leaves.

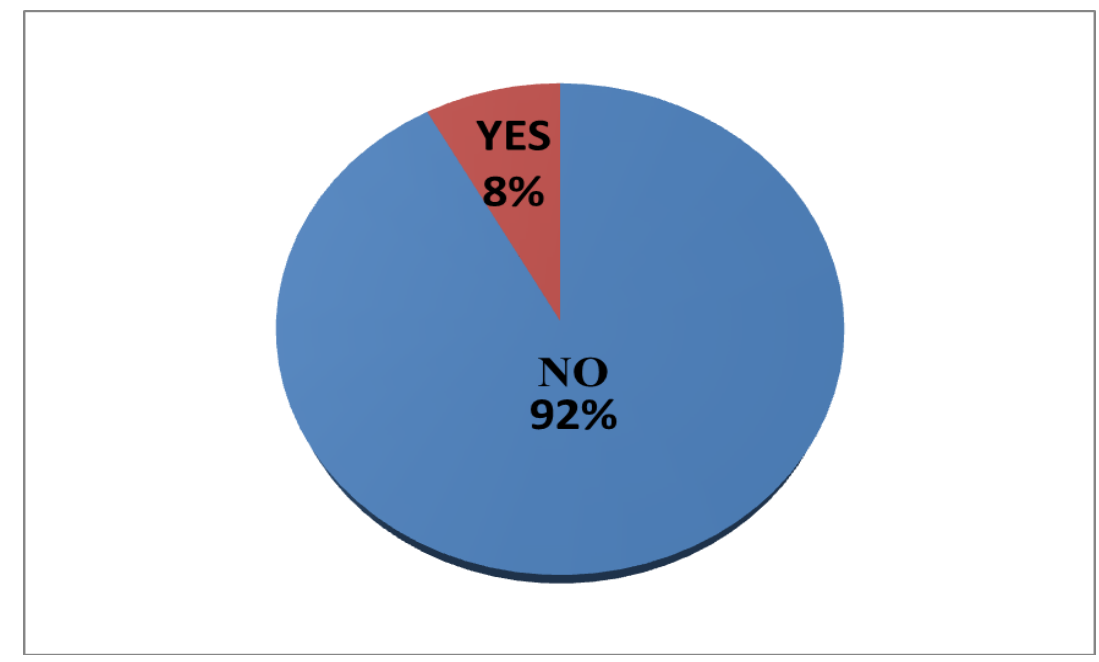

Fig.2. Direct tea marketing by factories. 
From the above figure, $92 \%$ claimed that the factories do not have direct marketing strategies of the processed green leaves. The organizations rely on brokers who look for markets on behalf of the factories. This has made the factories register minimal and varied revenue. Individual factories have contracted brokers who do the marketing and eventual selling. The amount of payment per kilo per factory depends on the strength of bargain of the broker contracted in the respective individual factory. On the other hand, $8 \%$ asserted that the factories by virtue of contracting the brokers have a direct involvement in marketing. They also felt that by endeavouring to buy only quality tea leaves and processing it into best grades, that in itself is a marketing strategy geared towards increasing revenue to be generated. The involvement is though perceived to be remote.

\section{Strategic Planning and Organizational Performance}

In assessing strategic planning and how it affects organizational performance, the study was meant to investigate whether the organizations in question have any strategic planning measures in place and if so be the case, how do they affect the performance of the factories .

Table 2: Strategic planning and Organizational performance.

\begin{tabular}{|c|c|c|}
\hline Response & Frequency & Percentage \\
No extent & 0 & 0 \\
\hline Very little extent & 0 & 0 \\
\hline Little extent & 3 & 6 \\
\hline Moderate extent & 6 & 12.5 \\
\hline Great extent & 18 & 37.5 \\
\hline Quite great extent & 14 & 29 \\
\hline Intense extent & 7 & 15 \\
Total & 48 & 100 \\
\hline
\end{tabular}

From table 2 the data collected on strategic planning and organizational performance as reflected above, no respondent agreed with the lack of planning at all as well as with the existence of strategic planning to a very little extent.Three respondents agreed that there is planning to little extent. For those respondents who agreed with the existence of strategic planning to little extent, they reported of inadequate planning arguing on the premise that planning in factories is only on paper and not in practice. They cited policy implementers failing to plan and implement the strategies which are drafted. Those respondents gave examples like some factories occasionally running out of fuel due to poor planning. To remedy this unforeseen challenge, the affected factories result to outsourcing for fuel or tea processing services from neighboring factories. The outsourcing compromises efficiency, increases costs and eventually negatively affects organizational performance.Six respondents agreed to a moderate extent that planning is moderately done. The respondents argued that due to moderate strategic planning, the factories have registered a below average performance. Eighteen respondents agreed there is planning to a great extent. 14 respondents agreed to quite great extent that the factories strategically plan to quite great extent. Finally 7 respondents agreed that strategic planning is done to an intense extent. Respondents who agreed to a great extent, quite great extent and intense extent argued that there is strategic planning that is adequate citing instances like procuring of fertilizes well in advance every year to ensure continuous harvesting and abundant supply of green leaves to the factories.

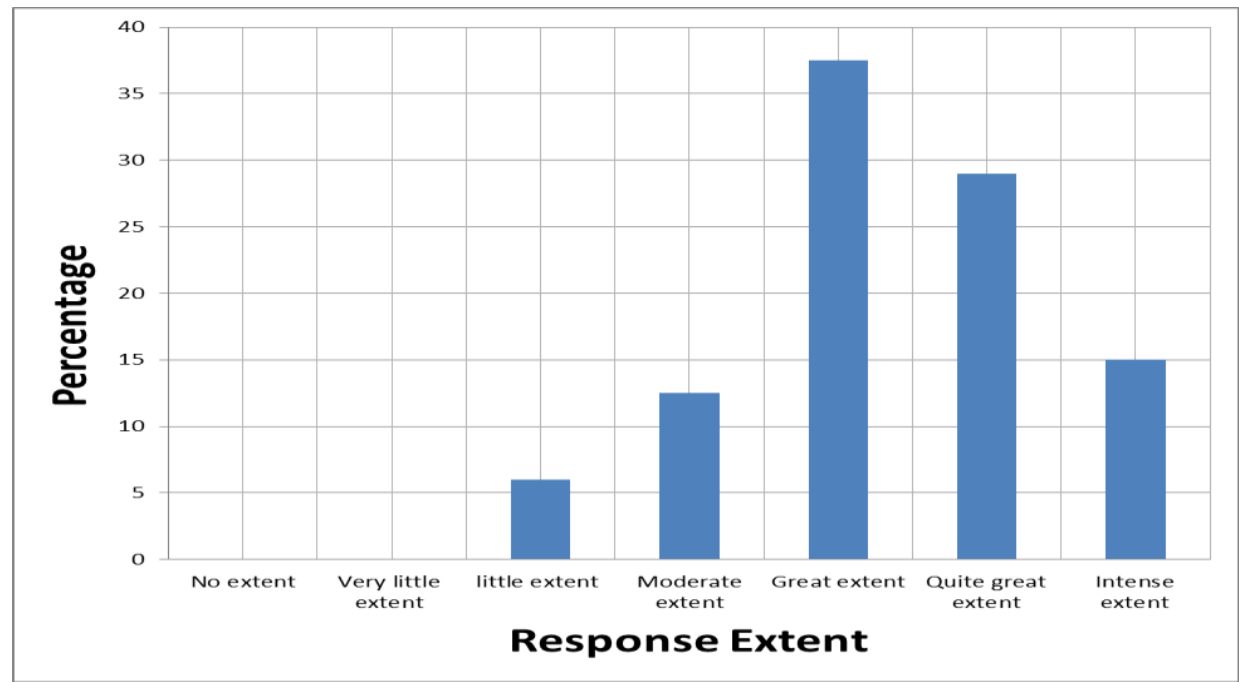

Fig. 3. Percentage extent of strategic planning 
From figure 3, no respondent agreed with the lack of planning at all as well as with the existence of strategic planning to a very little extent. In the two extents, that translates to $0 \%$. $6 \%$ of the respondents agreed that there is planning to little extent. $12.5 \%$ agreed to a moderate extent that planning is moderately done. $37.5 \%$ agreed there is planning to a great extent. $29 \%$ agreed to quite great extent that the factories strategically plan to quite great extent. Finally $15 \%$ agreed that strategic planning is done to an intense extent.

\section{Outsourcing strategy} and how it affects performance.

On this variable the study sought to investigate if the factories use outsourcing strategy

Table 3: Outsourcing strategy and organizational performance.

\begin{tabular}{|c|c|c|}
\hline Response & Frequency & Percentage \\
\hline Yes & 48 & 100 \\
\hline No & 0 & 0 \\
\hline Total & 48 & 100 \\
\hline
\end{tabular}

On outsourcing, all the 48 respondents unanimously agreed that there is outsourcing especially in areas of fuel when there is shortage. Outsourcing is also applied in processing and marketing. It was found that outsourcing is twofold; either it improves performance or lowers it. It was however reported that in most cases, it affects performance of factories negatively. For instance, when there is sudden shortage of fuel in the factories they normally result to outsourcing which causes delays in the tea leaves production processes and lowers quality of processed leaves because tea is supposed to be processed within specified time limits from the time of plucking. With such delays, performance definitely declines. Also during routine factory maintenance periods, the factory in question outsources the services of processing. Depending on the nature of the machine, the grades produced can be better or poorer. It was however found that because the factories offering outsourcing services must process their tea first before processing the one from another factory that causes delays hence lowers quality.On marketing, the study established that is the major challenge because the brokers who are contracted by specific factories to auction don't always bring the best bet because of competition from major tea producing countries in the world like Seri-Lanka. As a consequence, such factories don't perform better.

\section{Marketing strategy}

\section{Conclusion And Recommendations}

On marketing the study found out that there is no direct marketing strategy applied by the factories because factories rely on brokers who are contracted by the companies to market and finally sell the processed tea.

The study though found that the companies remotely influence the price to be fetched at the international market by insisting on buying only quality green leaves from the farmers. By so doing tea factories produce better grades which attract better prices globally.

\section{Strategic planning}

With strategic planning, the study found out that there is either minimal planning or no planning at all in majority of factories. For instance, because of inadequate planning most factories run short of fuel at unexpected times. This forces the affected factories result to outsourcing which causes dalayance and eventual compromise of quality of grades. This leads to poor organizational performance.

\section{Outsourcing strategy}

On outsourcing, the study found out that most factories use this strategy either by design or default. The common outsourced service by majority of factories is processing of tea leaves when the affected factories undertake routine maintenance practices. With outsourcing service, the study established that it increases costs, reduces quality of processed tea, wastes time and thus lowers the performance of the factories in question. The other outsourced service is marketing of the processed tea. The organizations use contracted brokers who exploit the companies thus making the factories perform poorly.

The study concludes that marketing strategy and planning strategy are important in organizational performance. These strategies if well drafted and executed can greatly improve the performance of KTDA factories. For outsourcing, the outsourced services and products cause unnecessary delays in leave processing and lowers quality of grades produced. This negatively affects the performance of the factories, though it salvages the operations of the factories rather than making the whole process stall. 


\section{Recommendations}

From the study findings and conclusions drawn, the strategic management practices in question namely; marketing, planning and outsourcing have a positive correlation with the performance of the factories. In this regard, the study recommends that for marketing strategy, KTDA factories should permanently employ professionally trained marketers who market the processed tea to fetch best prices in the global market. This will ensure increased revenue generation thus improving organizational performance.

On planning strategy, the factories should plan well in advance to ensure all the required resources like fuel are enough and ever in stock. On outsourcing strategy, the factories should also make prior arrangements and agreements with other neighbouring KTDA factories to prioritize and process the outside tea alongside their own to reduce spoilage.

\section{Recommendations for further research}

The study researched on the effect of strategic management practices which were marketing technology, planning and outsourcing and how they affect the performance of KTDA factories in Kisii county. There are other KTDA factories outside the county, the study therefore recommends that there is need for another research to investigate whether the findings will be true with the findings of this study. Also there is need for more studies to consider other management practices apart from the ones considered in this study and establish if they also affect the performance of KTDA factories.

\section{Conclusion And Recommendations}

The study concluded that e-procurement readiness in Nyamira County Government was readily implemented despite the challenges of applying e-procurement like lack of cooperation from top management ineffective computer system, long lead-time and incorrect stock status and lack of supplier cooperation. Eprocurement has experienced a good portion of it with its performance helping Nyamira County Government to the high levels like it has helped managers to reduce inventory control, minimized workforce overtime, high inventory turnover ratio improved consistency of time customer delivery and determine the most economical lot sizes for orders. In the study it was concluded that user training influenced the effective implementation of the government e-procurement system in Nyamira County through trained staff being able to use the system well. The fundamental aim of training is to help the organization achieve its purpose by adding value to its key resources the people it employs.

\section{Recommendations}

The study recommends that influence of user readiness on the implementation of government electronic procurement, the top management in different departments at Nyamira County Government should allocate enough resources for easy preparation on enhancing e-procurement to improve on its procurement performance.

On the effect of user training on implementation of Government electronic procurement system, Nyamira County Government should employ latest technological systems training to staff in doing their procurement activities so as they have their image to the public and society by reducing delivery time.

\section{Suggestions for Further Studies}

From the study, the researcher suggests that further studies should be done on the determinants of eprocurement on performance at Nyamira County Government. Other study should be carried out to establish strategies to be adopted by county governments to enhance procurement effectiveness and further research should be done on effect of staff skill on procurement innovativeness.

\section{References}

[1]. Ansoff.(1980). Strategies for Diversification. Harvard Business Review.

[2]. Aulak, P. \& Sarker, M.(2005). Strategic ambidexterity in international exploration of market, product and organizational boundaries. Academy of management best paper processing- international management division.

[3]. Bamey, J. B. (1986). Organizational culture: can it be a source of sustained competitive advantage? Academy of Management Review, 11: 656-665.

[4]. Barr, P.S. \& Glynn, M.A. (2004). Strategic Management Journal, 25(1),59-69.

[5]. Black Eisenhard, K. M. (1989). Making fast strategic decisions in high-velocity environments. Academy of Management Journal 32: $543-576$

[6]. Brian, T.(2000). The 100 Absolutely Unbreakable Laws of Business Success. Berrett Koehler Publishers.

[7]. Bryman, A. \& Bell, E. (2003). Business Research Methods. New York .Oxford.

[8]. Castanias, R. P., \& Helfat, C. E. (1991). Managerial resources and rents. Journal of Management,17:155-171.Traits,configurations and paths of sustainable competitive advantage. Journal (Special Issue): 131-148.

[9]. Cooper R. D. \& Emoly, C. W. (1995). Business research methods (5th ed.) McGraw, Hill companies.

[10]. David F. R. (1993). Concept of strategic management,(4 ${ }^{\text {th }}$ ed.).New York, Macmillan publishers.

[11]. Eisenhard, K.M. \& Brown, S.L.(1998). Competing on edge: Strategy as structure chaos. 
[12]. Erica, O.(2012). Strategic Planning Kit for Dummies, ( $2^{\text {nd }}$ ed.). John Wiley \& Sans, Inc.

[13]. Fredrick. \& David,(2011). Strategic Management Concepts. Oxford University Press.

[14]. Graetz, F.(2002). Strategic thinking versus strategic planning towards understanding the complementaries. Management decision.

[15]. Heller, R,(1991). The complete guide to modern management. London: Gold Arrow Publications.

[16]. Hersy, P. \& Blanchard, K.(1988). Management of organizational behavior: utilizing human resources. New Jersey: Prentice- Hall inc.

[17]. Hitt, M., \& Ireland, D. (1986). Relationships among corporate level distinctive competencies, diversification strategy, corporate strategy and performance. Journal of Management Studies, 23: 401-416.

[18]. Hunger. \& Willen.(2010). Essentials for Strategic Management. Iowa State University.

[19]. J. A., \& Boal Conner, K. R., \& Prahalad, C. K. (1996). A resource-based theory of the firm: Knowledge versus opportunism. Organizational Science, 7: 477-501.

[20]. John, A.(1968). Corporate Planning: A practical guide. Allen \& Unwin Ltd.

[21]. Kiggudu, M.(1989). Management organization in developing countries: An operational and strategic approach. Kumerian Press Library.

[22]. Kinyili,M. (2003). Diagnostic Study of the Tea Industry in Kenya, Export Promotion Council

[23]. Kombo, D. \& Tromp, D.(2006). Proposal and Thesis Writing: An introduction. Nairobi. Paulines Publication.

[24]. Kothari, C. (1985). Research Methodology: Methods and techniques. New Delhi. New international.

[25]. Lorenzen, M.(2006). Strategic Planning for Academic Library instructional Programming. Illinois Libraries 86, no.2, 22-29.

[26]. Lumpkin,G.T., \& Thompson \& Strickland, A. J. (1995). Strategic management concept and cases, (9 $9^{\text {th }}$ ed.). Richard Inc.

[27]. Martin, K. \& Agina, C.(2002). SPSS for institutional researchers. Lewisburg Pennsylvania: Bucknell University Press.

[28]. Micheal, E.Porter.(2001). How competitive forces shape Strategy. Harvard Business review.

[29]. Mugenda, O.M., \& Mugenda, A.G.(2003). Research methods: Quantitative and qualitative approaches. Nairobi: Acts Press.

[30]. Mutai, K. (2001). How to write dissertation on systematic and simplified approach. Ovendelhi:Thelley publishers.

[31]. Nasiurma, D.K.(2006). Survey Sampling theory and methods. University of Nairobi Press.

[32]. Numann, W.L.(2000). Social research methods qualitative approach. Boston: Delyn Boston Publishers.

[33]. Nyangito, H.O.(2000). Policy and Legal framework for the tea subsector and the impact of liberalization in Kenya. Kenya Institute for Public Policy Research and Analysis: Government Printer.

[34]. Orotho, J.A . (2005). Techniques of writing Research Proposals and reports in education and social sciences. Nairobi: Masola Publishers.

[35]. Patrick, J.B \& Suzanne, R.(1993). Successful strategic planning: A guide for Non-Profit Agencies and Organizations. Newbury Park: Sage Publication.

[36]. Powell, T.C. (1997). Information Technology as Competitive Advantage: The role of human, business, and technology resources. Strategic Management Journal, 18: 375-405.

[37]. Powell,T.C. (1992). Strategic Planning as Competitive advantage. Strategic Management Journal. 13: 551-558.

[38]. Sagimo, P.(2002). Management dynamic: Towards efficiency, effectiveness, competence and productivity. East Africa publishers.

[39]. Tea Research Foundation of Kenya. (2011). Strategic Plan 2010-2015. Retrieved on February 14, 2014, from:http://www.tearesearch.or.ke

[40]. The Tea Board of Kenya. (2012). Tea Growing and Production in Kenya. 